\title{
Rosmarinus officinalis L. (Rosemary): An Ancient Plant with Uses in Personal Healthcare and Cosmetics
}

\author{
Francisco José González-Minero ${ }^{1, *(\mathbb{D})}$, Luis Bravo-Díaz ${ }^{2}$ and Antonio Ayala-Gómez ${ }^{3}$ \\ 1 Department Plant Biology and Ecology (Botany), Faculty of Pharmacy, University of Seville, \\ 41012 Sevilla, Spain \\ 2 Department Pharmacology, Faculty of Pharmacy, University of Seville, 41012 Sevilla, Spain; luisbravo@us.es \\ 3 Department Biochemistry and Molecular Biology, Faculty of Pharmacy, University of Seville, \\ 41012 Sevilla, Spain; aayala@us.es \\ * Correspondence: minero@us.es; Tel.: +34-95-455-7714
}

Received: 9 September 2020; Accepted: 29 September 2020; Published: 3 October 2020

check for updates

\begin{abstract}
This work is a bibliographical review of rosemary (Rosmarinus officinalis) that focuses on the application of derivatives of this plant for cosmetic products, an application which has been recognized and valued since Ancient Egyptian times. Rosemary is a plant of Mediterranean origin that has been distributed throughout different areas of the world. It has many medicinal properties, and its extracts have been used (mainly orally) in folk medicine. It belongs to the Labiatae family, which contains several genera-such as Salvia, Lavandula, and Thymus-that are commonly used in cosmetics, due to their high prevalence of antioxidant molecules. Rosemary is a perennial shrub that grows in the wild or is cultivated. It has glandular hairs that emit fragrant volatile essential oils (mainly monoterpenes) in response to drought conditions in the Mediterranean climate. It also contains diterpenes such as carnosic acid and other polyphenolic molecules. Herein, the botanical and ecological characteristics of the plant are discussed, as well as the main bioactive compounds found in its volatile essential oil and in leaf extracts. Afterward, we review the applications of rosemary in cosmetics, considering its preservative power, the kinds of products in which it is used, and its toxicological safety, as well as its current uses or future applications in topical preparations, according to recent and ongoing studies.
\end{abstract}

Keywords: antioxidants; cosmeceuticals; medicinal plants; pharmacology; rosemary; Rosmarinus officinalis; skin care

\section{Introduction}

The World Health Organization defines health as a state of complete physical, mental, and social well-being, and not as only the absence of illness. This definition has not changed since 1948 [1]. To achieve physical and mental well-being, it is necessary to prevent the occurrence of pathologies and to promote anti-aging. Thus, caring for one's personal appearance and using cosmetic products are very important. This situation is not new, as humans have had a special interest in taking care of the external appearance of the body since ancient times [2]. Recently, a work was published in which an improvement in self-esteem was observed in Australian women voluntarily subjected to the daily use of certain cosmetics [3]. In recent decades, the use of cosmetics has become a mass phenomenon thanks to film, television, and, especially now, the use of social networks [4]. However, people not only want to appear beautiful, but also want to use natural, healthy, and safe products. For this reason, natural products such as plants are used as they are often considered non-toxic [5]. Consumers also demand that personal care products must be of good quality, and are interested in the characteristics of the products they are using, seeking scientific backing to guarantee the properties that appear on 
brand labels [5], even if those products do not have drug status [6]. Fortunately, the cosmetic industry is aware of this, and is becoming more demanding with the products they make [7].

One of these plants is rosemary (Rosmarinus officinalis), a plant with medicinal properties [8], of which extracts appear in the composition of hundreds of cosmetics. A Google search of the words "Rosmarinus" and "cosmetics" returns approximately 2,390,000 results (as of August 2020). In this search, it was observed that derivatives of rosemary are formulated in essential oils for massages and aromatherapy, rosemary alcohol, gels, shampoos, soaps, rosemary water, cleansing milk, deodorant, anti-wrinkle cream, aftershave lotion, hydrating facial cream, cream for the eye contour area, etc.

Since 2000, an average of 120 papers have been published per year dealing with various aspects of rosemary [9]. The latest reviews demonstrate its phytochemical, biological, and nutritional properties [9,10]; its anti-inflammatory power [11]; its power as a therapeutic and prophylactic agent [12]; and its topical applications [13].

Taking this background into account, we present a review of Rosmarinus officinalis from a cosmetic perspective, comprising the following sections: The history of the plant from an ethnomedicinal and cosmetic point of view, its botanical aspects, its ecological aspects, including comments on Mediterranean aromatic plants, its phytochemistry or secondary metabolites as well as their biological activity, and the applications of the plant in cosmetics. We hope that at the end of this work, cosmetic professionals will have a complete vision of this plant, and that when reading the label of a Rosmarinus officinalis product, they will know its full trajectory, from its natural environment to its presence in the formulations of cosmetic or cosmeceutical products.

\section{Methodology}

The Web of Science (WoS), Scopus, PubMed, and Wiley Online Library databases were used for this bibliographical review. The keywords used were "Rosmarinus officinalis" and "cosmetics", appearing in the titles of the works or in the keywords. The data obtained included 140 results from WoS, 95 from Scopus, 65 from PubMed, and 48 from Wiley, some of which were duplicated or did not contain information relevant to this study. A total of 63 works were selected from these databases. Almost all were written between the year 2000 and the present. This information was complemented by another bibliography, consisting mainly of books, which are difficult to access online.

\section{Results and Discussion}

\subsection{Historical Fragments Concerning the Use of Rosemary in Medicine and Cosmetics}

Rosemary has been one of the best-known plants since ancient times. The Ancient Egyptians used creams and oils for protection against high temperatures and desert heat. Rosemary was one of the ingredients of these products, which were formulated together with other plant extracts such as myrrh, thyme, marjoram, chamomile, and cedar [14]. Bouquets of rosemary were placed in the tombs of the Egyptian pharaohs to perfume their journey to the underworld [15]. There is evidence from around the year 220 BC of the introduction of rosemary in China [16].

Dioscorides (40-90 BC) named rosemary Libanotis coronaria (pre-Linnaean nomenclature), in reference to its property of toning the fatigued body (through topical use) [17]. According to De Materia Medica, a forerunner of modern pharmacopoeias, rosemary was used in aromatherapy to perfume rooms and as an insecticide. The fathers of ancient medicine-namely, Hippocrates, Avicenna, and Galen-used ointments of rosemary flowers and leaves macerated in olive oil to treat joint pain and as a vulnerary to heal wounds [18].

Throughout the centuries, Rosmarinus spp. have been used in folk medicines as an antispasmodic, diuretic, antiepileptic, carminative, renal colic, antirheumatic, and expectorant; as well as for diabetes, dysmenorrhea, heart diseases, and for relieving respiratory disorders $[19,20]$.

Rosemary was present at the beginning of modern cosmetics in Europe, dating back to the 14th century in Montpellier (France), when the old Libanotis coronaria came to be referred to as the Queen of 
Hungary's water or spirits of rosemary, a hydroalcoholic solution of the essence of rosemary used by the Queen Consort of Hungary (1305-1380) [2].

Rosemary has had other remarkable appearances throughout history. In the great London plague of 1665 (Yersinia pestis), the vapors of the plant were inhaled when traveling through infected areas. During World War II, mixtures of rosemary leaves and juniper berries were burned in French hospitals to kill germs [11].

Finally, it is worth noting that rosemary is the most frequently used plant in commercial cosmetics in Egypt today, where there is an ancient tradition of using plants in cosmetics. Rosemary is followed in popularity by Cinnamomum verum, Cocos nucifera, Olea europaea, Zingiber officinale, and Prunus dulcis [21].

\subsection{Botany}

Taxonomical position [22]:

Clade: Angiosperms

Order: Lamiales

Family: Lamiaceae or Labiatae

Genus: Rosmarinus

Number of species: Five

Accepted name: Rosmarinus officinalis L. (Salvia rosmarinus Scheid.)

Synonyms: 21 ( $R$. angustifolius, R. latifolius, R. tenuifolius, etc.)

Common name (some European countries): Romero (Spanish), alecrim (Portuguese), rosemary (English), rosmarin (French and German), rosmarino (Italian), and $\delta \varepsilon \vee \delta \rho \circ \lambda \iota \beta \alpha \nu_{0}$ (Greek).

Commercial varieties: 22 different cultivars, the most common varieties being: "Arp", "Hill1" (synonymous "Hill Hardy"), "Albus", "Bendenen Blue", "Goodwin Creek", "Herb Cottage", "Logee's Light Blue", "Jessup's Upright", "Russian River" and "Salem" [23]. Morales indicates that there are more than 100 varieties in the world [24].

Brief description of the plant (adapted from the description of Rosmarinus officinalis in Flora Ibérica [24]): Rosemary is an evergreen shrub up to $1.8 \mathrm{~m}$ tall, erect or procumbent. The leaves $(10-41 \times 1-3 \mathrm{~mm})$ are non-petiolate, of variable size in the same branch; they are strongly recurved and are sharpened, with a linear or lanceolate shape. The upper surface is green and the underside is whitish due to the presence of numerous hairs: glandular (capitate and peltate) and non-glandular trichomes (Figure 1). Its flowers are small, arranged in short clusters, and they have a purple or white bilabiate corolla (8.5-13.5 mm).
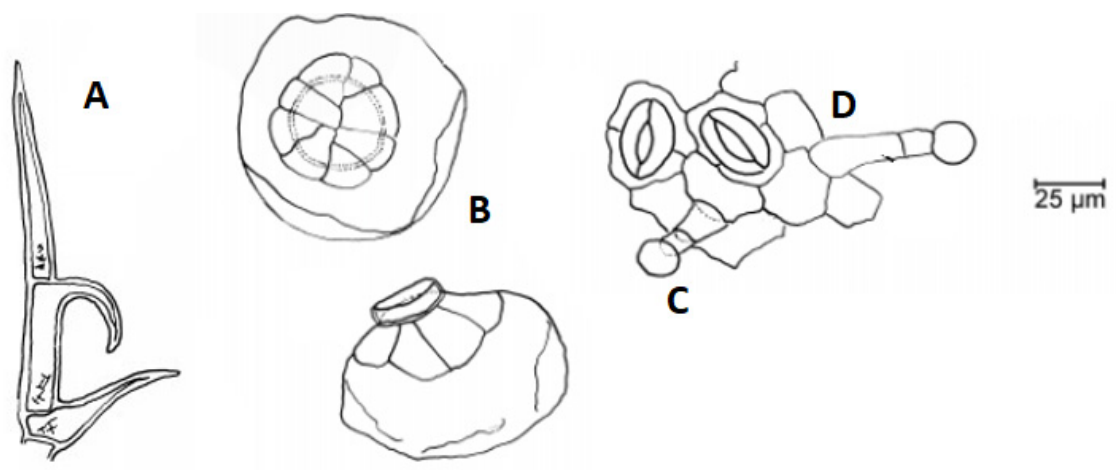

Figure 1. (A) Non-glandular trichome; (B) peltate octocellular glandular trichome, with a large secretory cavity; (C) stomata; (D) capitate glandular trichome.

Etymology [25]: In the Spanish translation of Dioscorides by Andrés de Laguna (1558), the words Romarinus and romero appear, referring to rosemary. Later, botanists kept this name as Rosmarinus hortensis angustiore folium, until Linnaeus, who was a doctor and collected much of the botanical knowledge from antiquity, named it Rosmarinus officinalis in 1753. Phylogenetic studies have since 
suggested that rosemary in fact belongs to the genus Salvia, being called Salvia rosmarinus [26]. The word Rosmarinus possibly comes from the Greek Rhopos (bush) and Myrinum (aromatic) [24]. The specific epithet officinalis (given by Linnaeus) refers to the medicinal use of the plant.

Geographical distribution [24,27]: The plant is native to the Caucasus and to the Eastern Mediterranean, although it has been introduced into many areas of the world since ancient times as an ornamental species (e.g., the rest of Europe, Chile, and China). However, it is in countries with a Mediterranean climate where it is most cultivated (Figure 2).

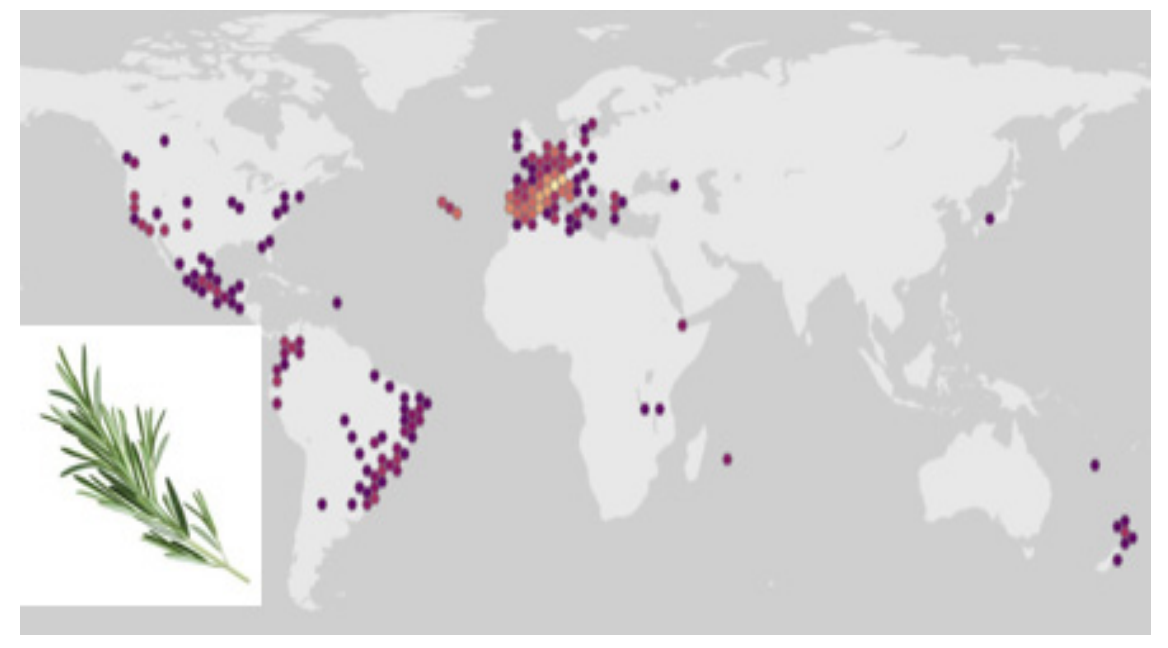

Figure 2. Geographic distribution of Rosmarinus officinalis according to the Global Biodiversity Information Facility (GBIF) [27]. For a better understanding of the graphic, see text. GBIF is an international network and research infrastructure funded by the world's governments, aimed at providing anyone, anywhere, with open access to data about all types of life on Earth.

In Figure 2, no marks are shown in China, Pakistan, India, South Africa, etc. This does not mean that rosemary is not found in these countries, but that it has not been registered in the Global Biodiversity Information Facility (GBIF) database. It lives between 0 and $1600 \mathrm{~m}$ above sea level and is indifferent to the type of soil. It does not grow well in very humid or very cold geographical areas. Its flowering period takes place between the end of December and April in the Mediterranean region (northern hemisphere).

Crop: Spain is the main producer of rosemary in the world for commercial purposes, followed by France, Italy, and Tunisia [28]. Some regions of Asia, the United States, Mexico, and South Africa also grow it. As it is a very small crop, there are no official reliable measurements of its quantity of production. In 2005, the USA imported 109 tons of rosemary oil [29].

\subsection{Ecology of Rosemary and Other Labiates in Mediterranean Forests}

The Lamiaceae family has a cosmopolitan distribution, although it is especially represented in geographical areas with a Mediterranean climate and in dry climates [30]. The Mediterranean climate of southern Spain is characterized by high solar radiation, irregular rainfall throughout the year, and a period of drought between May and September (summer in the northern hemisphere). During this dry period, maximum daily temperatures frequently exceed $30^{\circ} \mathrm{C}$ [31]. Plants must adapt to these situations of water stress and high temperatures. Mediterranean plants make a large investment in the biosynthesis of polyphenols, which are versatile compounds that help plants to adapt to harsh environments. On those days with the highest solar radiation, many Mediterranean plants increase the synthesis of flavonoids. These flavonoids have the function of sunscreens for the plants themselves [32].

Another resource that the Labiatae and other Mediterranean plants have is the ability to increase their production of volatile essential oils. This is why the forest has a fragrant smell. Thomson et al. [33] 
attributed this property to the ability to attract pollinating insects. In the specific case of rosemary, Olmos et al. [34] showed that in periods of water stress and temperature increase, the volatile essential oils evaporate, the great secretory cavities of the glandular hairs become disorganized, and, therefore, the temperature of the plant drops. This situation is reversible when conditions are normalized (Figure 3).

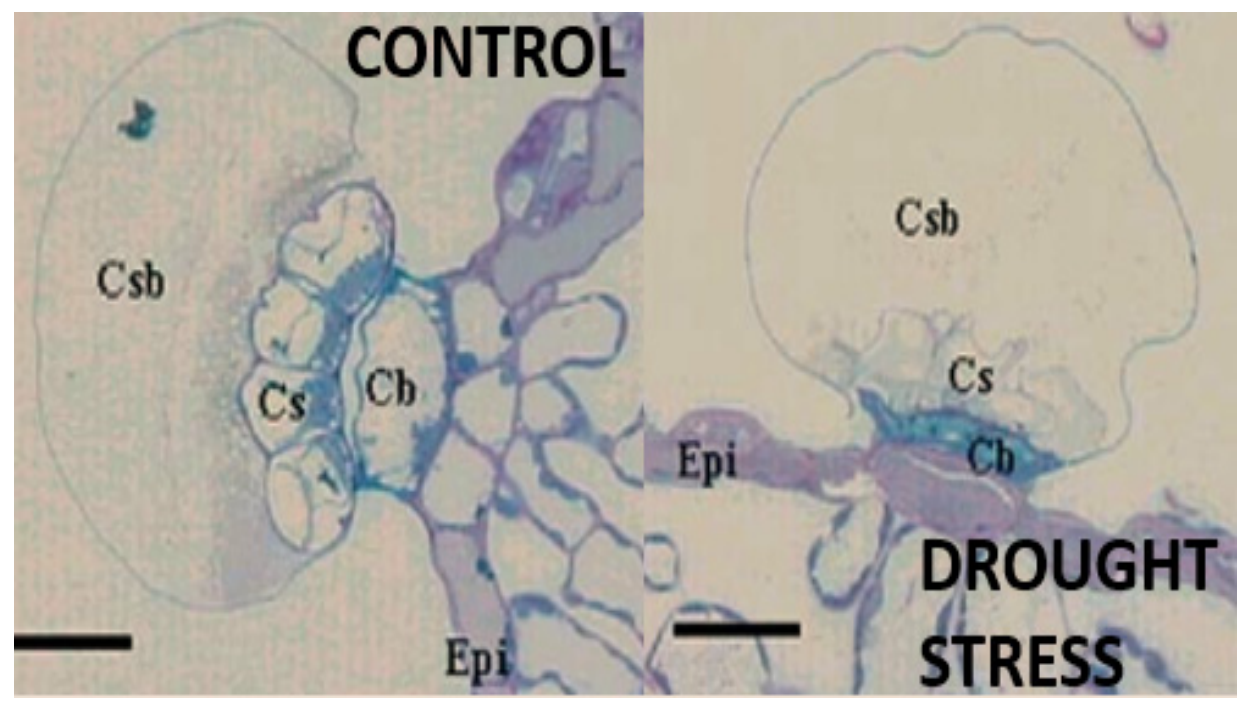

Figure 3. Changes in the peltate glandular trichomes of rosemary. $\mathrm{Cb}$, basal epidermal cell; $\mathrm{Csb}$ and $\mathrm{Cs}$, secretory cells; CsB, great cavity or secretory head; Epi, epidermis. Bars: $25 \mu \mathrm{m}$. The cuticle is not seen in Csb. Image courtesy of [34].

This is in agreement with the report of Tawik et al. [28]. The oil harvest is much higher in summer than in winter: In summer, 12 arrobas $(1$ arroba $=11.5 \mathrm{~kg})$ of plant material are needed to produce around $1 \mathrm{~kg}$ of oil, whereas in winter, 20 arrobas are required.

Boix et al. [35] indicated that these essential oils are found in peltate hairs and, as can be observed by gas chromatography-mass spectrometry analysis (GC-MS), are mostly monoterpenic in nature. Meanwhile, Staudta et al. [36] argued that the synthesis of isoprene derivatives increases with temperatures up to $40^{\circ} \mathrm{C}$ and must be released because they do not accumulate in the plant. These explanations help to understand the reason why the Labiatae family, and rosemary in particular, produce a large quantity of phytochemicals [37], which are highly valued in cosmetics [38].

In the southern and eastern areas of Spain, rosemary is grown, together with other plants of the Labiatae family (lavender (Lavandula), thyme (Thymus), oregano (Origanum), and sage (Salvia)) [39]. In this geographical area, there are also plants such as myrtle (Myrtus, eucalyptus family), "jaras" (Cistus), mastic shrubs (Pistacia), and trees such as olive trees (Olea europaea), pine trees (Pinus), and wild oaks (Quercus) (Figure 4). With these comments, we put rosemary in its ecological context, accompanied by other plants that are currently being studied for their cosmetic applications [40-44]. 


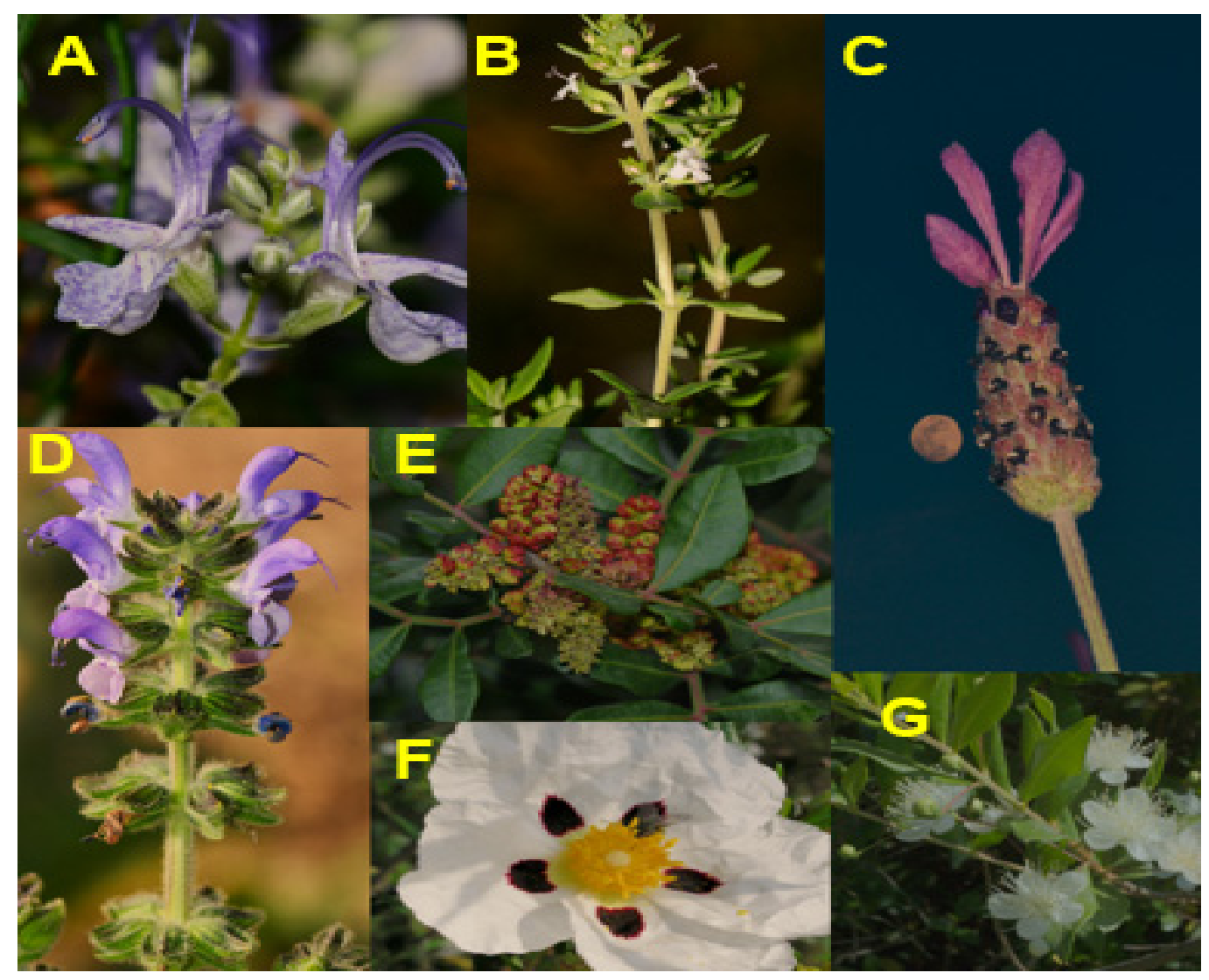

Figure 4. (A) Rosmarinus officinalis; (B) Thymus mastichina; (C) Lavandula pedunculata; (D) Salvia verbenaca; (E) Pistacia lentiscus; (F) Cistus ladanifer; (G) Myrtus communis. Photos courtesy of Dr. Rafael González-Albaladejo.

\subsection{Rosemary Phytochemistry and Biological Activity}

The bioactive compounds of rosemary—such as monoterpenes, diterpenes, and polyphenols—are products obtained from plant materials by steam distillation or similar processes. The most used classic extraction methods of essential oil are maceration, decoction, hydrodistillation, and solvent extraction. Others, related to so-called green chemistry, are supercritical fluid extraction (SCF) and the use of microwave and ultrasound methods $[9,45]$.

Table 1 shows the most abundant bioactive molecules found in rosemary. It is only a summary, since the final composition varies depending on the variety, origin, part of the plant, and the extraction method. This will be discussed briefly later. The molecular structures are shown in Figure 5. According to Andrade et al. [9], the most frequently studied molecules related to rosemary are volatile essential oil $(27 \%)$, carnosic acid $(30 \%)$, rosmarinic acid $(12 \%)$, and ursolic acid $(6 \%)$.

Table 1. Main bioactive molecules in rosemary.

\begin{tabular}{ll}
\hline Main Monoterpenes & $\begin{array}{l}\text { 1,8-Cineole (eucalyptol), Camphor (ketone), } \alpha \text {-pinene, Borneol, } \beta \text {-pinene, } \\
\text { Limonene y p-cymene, Verbenone (ketona), and Sesquiterpenes } \\
(\beta \text {-caryophyllene) }\end{array}$ \\
\hline Main diterpenes & Carnosic acid, carnosol, rosmarol, epirosmanol, isorosmanol, and rosmaridifenol. \\
\hline Main triterpenes & Oleanolic acid, ursolic acid, betulin, $\alpha$-amyrin, and $\beta$-amyrin. \\
\hline Flavonoids & $\begin{array}{l}\text { Luteolin, apigenin, genkwanin, diosmetin, hispidulin, 5-hidroxi-7, } \\
4^{\prime} \text {-dimetoxi-flavone, and cirsimaritin. }\end{array}$ \\
\hline Phenolic acids & Caffeic acid, chlorogenic acid, and rosmarinic acid. \\
\hline
\end{tabular}




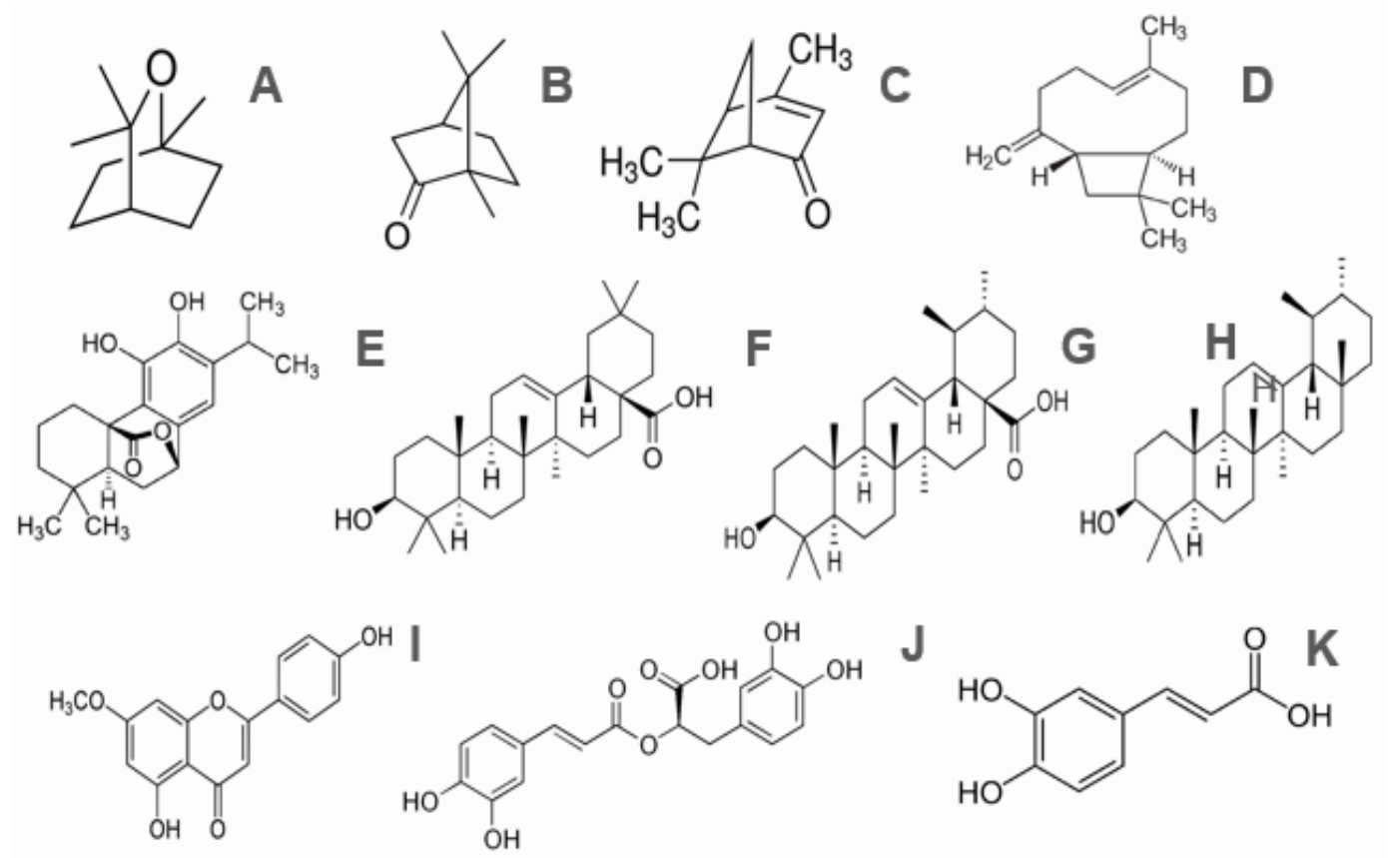

Figure 5. Structures of the main bioactive molecules in rosemary: (A) 1.8 cineole; (B) camphor; (C) verbenone; (D) $\beta$-caryophyllene; (E) carnosol; (F) oleanolic acid; (G) $\alpha$-amyrin; (H) ursolic acid; (I) genkwanin; (J) rosmarinic acid; (K) caffeic acid.

There is a large body of scientific literature in which the chemical composition of rosemary is discussed $[9,11,15,23,37,46-48]$, and this is increasing as more sophisticated methods of analysis are used to examine extracts [49]. In this work, we only study volatile essential oil (Rosmarini aetheroleum) and the non-volatile part of the leaf extract (Rosmarini folium), which are the two forms collected in the Royal Spanish Pharmacopoeia of 2015, which is equivalent to the current European Pharmacopoeia [8].

In plants, the final composition of the mixture of bioactive molecules varies depending on the geographical origin, the part of the plant used, the stage of development at the time of harvest, and the type of material used (dry leaves, green leaves, flowers, etc.) $[15,35,45,46,50,51]$, as well as the type of extraction. This seems obvious and is confirmed in many cultivated plants [52]. Because of this, it would be convenient for the consumer to have access to this information on the product label, to ensure good practices in the cosmetic industry. For example, in the composition of volatile essential oils, the Royal Pharmacopoeia distinguishes the type of essential oils from Spain and those from Morocco and Tunisia (Table 2). The type from Spain is richer in $\alpha$-pinene, whereas that from Morocco and Tunisia is richer in camphor.

In Serbia, it has been observed that the composition of the volatile fraction of rosemary changes when the same plants are analyzed throughout the year. The authors reported that monoterpenes range from $92.3 \%$ to $95.3 \%$, especially the oxygenated ones (52.1-62\%). They also reported six chemotypes depending on the dominant molecule and another six intermediates for the same genotype [51]. Fiume et al. [49] confirmed that the amount of carnosol and carnosic acid present in the extract varies with the method of extraction. The level of carnosol and carnosic acid found in a rosemary extract prepared from a partially deodorized ethanol extract of rosemary is between $5 \%$ and $7 \%$, whereas in an extract prepared with supercritical carbon dioxide, the level increases up to $30 \%$. 
Table 2. Composition of volatile essential oils. Gas chromatographic analysis of Spanish-type and Moroccan- and Tunisian-type rosemary oil (Spanish Royal Pharmacopoeia 2015 = European Pharmacopoeia) [8].

\begin{tabular}{ccc}
\hline Chemical Constituents & Spanish Rosemary Oil \% & Moroccan and Tunisian Rosemary Oil \% \\
\hline$\alpha$-pinene & $18-26$ & $9-14$ \\
camphene & $8-12$ & $2.5-6$ \\
$\beta$-pinene & $2-6$ & $4-9$ \\
$\beta$-myricene & $1.5-5$ & $1-2$ \\
limonene & $2.5-5$ & $1.5-4$ \\
cineole & $16-20$ & $38-55$ \\
p-cymene & $1-2.2$ & $0.8-2.5$ \\
camphor & $13-21$ & $5-15$ \\
bornil acetate & $0.5-2.5$ & $0.1-2.6$ \\
$\alpha$-terpineol & $1-3.5$ & 5 \\
borneol & $2-4$ & $1.5-15$ \\
verbenone & $0.7-2.5$ & Max 0.4 \\
\hline
\end{tabular}

In the essential oil of rosemary, we must distinguish between the volatile fraction and the non-volatile leaf extract. By distillation, volatile chemical compounds, mono- and sesquiterpene hydrocarbons, alcohols, ketones, and esters are obtained (Table 2). Other products are extracted by solvents. In the volatile essential oil of rosemary, up to 150 different compounds have been found (the frequently reported molecules are 1,8-cineole, $\alpha$-pinene, and camphor), with most of them being monoterpenes [11]. On the other hand, three different chemotypes can be differentiated: cineoliferum (with a high percentage of 1,8-cineole), camforiferum (with more than $20 \%$ camphor), and verbenoniferum (with more than $15 \%$ verbenone) $[15,46]$.

Antioxidant properties have been attributed to volatile essential oils, as confirmed by chemical methods such as those using 2,2-diphenyl-1-(2,4,6-trinitrophenyl) hydrazyl (DPPH) and 2,2'-azino-bis-3-ethylbenzothiazoline-6-sulfonic acid (ABTS) radical scavenging tests [37]. In vivo, these oils have protective effects on alloxan-induced hyperglycemia in rats, combatting hepatic and renal oxidative stress. The same authors also evaluated the antioxidant activity of renal enzymes, such as superoxide dismutase (SOD) and catalase (CAT), as well as DPPH radical scavenging activity. These methods have been used by other authors to measure antioxidant activity in extracts from some plants [53].

Volatile essential oils have also shown anti-inflammatory activity. Borges et al. [11] suggested that the anti-inflammatory effect of volatile essential oils occurs primarily through inhibition of NF-kB transcription and suppression of the arachidonic acid cascade. Their antifungal and bactericidal activity has also been evaluated in vitro [54,55], which Senena et al. [56] attributed to $\alpha$-pinene and, to a lesser extent, $\beta$-pinene and 1.8 cineole. However, Hussain et al. [57] indicated that the main agent of the bactericidal action of essential oil is 1.8 cineole. Chávez-González et al. [54] suggested that future studies should be deepened on the bactericidal capacity of the volatile essential oil of rosemary as a new resource for fighting infections, given the growing resistance to antibiotics.

Carnosic acid is unique to the Labiatae family. It was first isolated from Salvia officinalis and later from rosemary. It is a diterpene that accumulates in the chloroplasts of the leaf. It is converted to carsonol in the dry leaf, to which $90 \%$ of the antioxidant capacity of rosemary extracts is attributed [58]. Moreover, aside from its potential uses in cosmetics, the authors of [58] suggested that carnosic acid has antiproliferative and anticancer properties. Carnosic acid is accompanied by other bioactive molecules with great therapeutic potential, such as diterpenes (rosmarol), triterpenes (ursolic acid and oleanolic acid), and polyphenols (flavonoids, rosmarinic acid, and phenolic acids). The latter have high antioxidant activity and are skin protectors [59] (Table 1).

Lee et al. [38] carried out chemical and biological tests on different Lamiaceae extracts in $70 \%$ acetone (Rosmarinus, Lavandula, Salvia, Ocimum, and Origanum). All of the extracts showed 
antioxidant effects in the DPPH test, with the extracts of Origanum and Lavandula being the most effective by this method. Rosemary showed greater absorption power for UVA and UVB radiation, and greater activity in an anti-Staphylococcus aureus test. These properties have to be taken into account as a skin care product.

As can be seen, rosemary has good antioxidant potential, perhaps as a consequence of the synergistic action of its bioactive molecules to neutralize reactive oxygen species (ROS) and lipid peroxidation, which are responsible for cell damage and diseases such as diabetes, cancer, and neurodegenerative diseases, including damage and premature aging of the skin. Calabrese et al. [60] isolated a compound from the hydrophilic fraction of an aqueous extract of methanol and named it Rosm1, and this biomolecule has been tested in human volunteers. It was concluded that Rosm1 has a strong antioxidant capacity to neutralize ROS, similar to vitamin E, and is able to inhibit lipid peroxidation in the skin. Figure 6 shows a general scheme of the lipid peroxidation mechanism, which has three stages: initiation, propagation, and termination.

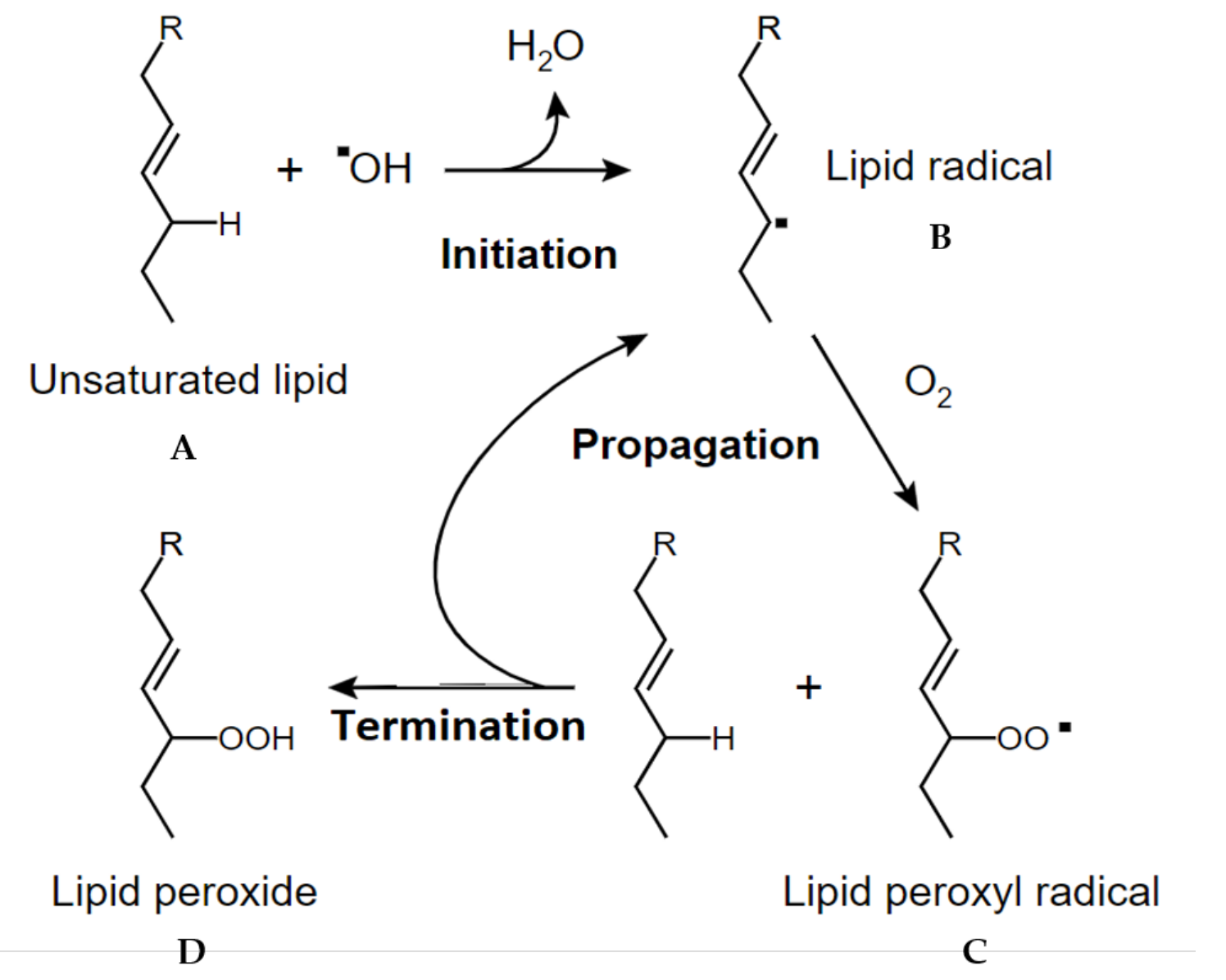

Figure 6. Mechanism of lipid peroxidation. (A) Unsaturated lipid; (B) radical lipid; (C) lipid peroxyl radical; (D) lipid peroxide.

Figure 7 shows the reaction mechanism of a phenolic compound in which the free (unpaired) electrons of the oxidants are stabilized in the form of ketones. This reaction is not reversible and the polyphenol is consumed [37]. 


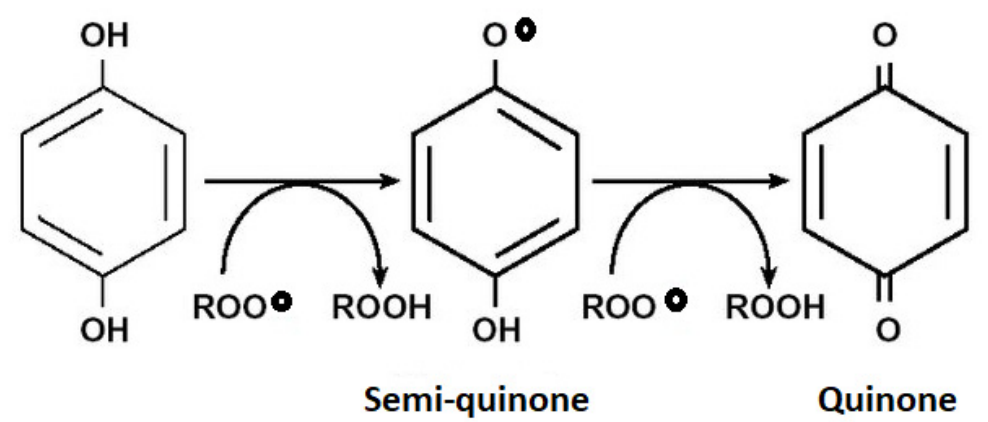

Figure 7. General oxidation reaction mechanism of a phenolic compound.

For a better understanding of the medicinal potential of rosemary, we recommend reading the work of Oliveira et al. [12], in which the authors summarize the therapeutic and prophylactic capacity that this plant has for different diseases, based on in vitro and in vivo studies.

\subsection{Use of Rosemary in Food and Cosmetics, and Examples of Other Topical Actions}

The phytochemical potential of both the essential oil and the extracts of the rosemary leaf are exploited in the food, pharmaceutical, and cosmetic industries. The European Food Safety Authority (EFSA) has considered rosemary extract a food additive since 2008 (EFSA-Q-2003-140) [61], because it contains several compounds that have been proven to exert antioxidative functions. Since 2008, the EFSA has revised this status several times, estimating higher safety margins in the use of this additive [62]. The amount required depends on the type of food, and is the sum of carnosol and carnosic acid content, these being the most powerful antioxidants in the extract [10]. These molecules are also allowed as food additives in Japan and China, but have not achieved this status in the United States [58].

In the production of cosmetics, the same possibility has been considered. Cosmetic products deteriorate due to the oxidation of their fatty components by fungi and bacteria. The microorganisms that represent the most frequently occurring microflora in cosmetic and food products are the Gram-positive bacteria Bacillus subtilis, Staphylococcus epidermidis, and Staphylococcus aureus; the Gram-negative bacteria Pseudomonas aeruginosa, Escherichia coli, and Salmonella abony; the yeasts Saccharomyces cerevisiae and Candida albicans; the mold Aspergillus niger [63]. For this reason, for more than two decades, trials have been carried out using extracts and essential oils of rosemary as bactericidal and antifungal agents in cosmetic preparations [64]. Satyal et al. [65] reported the antimicrobial activity and cytotoxicity of $\alpha$-pinene, 1,8 cineole, camphene, $\beta$-myrcene, camphor, and borneol, which are contained in rosemary oil. A moderate effect with the Gram-positive and Gram-negative group was also demonstrated. Gauch et al. [66] observed the potent inhibitory and fungicidal activity of rosemary essential oil against specific strains of Candida, which was verified in four strains of Candida (C. albicans, C. dubliniensis, C. parapsilosis, and C. krusei).

All of these previous works aimed at demonstrating the effectiveness of rosemary not only as a preservative in food, but also in cosmetics. As indicated in the introduction, consumers demand products of a natural and safe origin. In the scientific literature, cases have been published in which chemical preservatives - for example, parabens - were found to be topical inducers of breast cancer [67]. For this reason, plant preservatives have been studied, such as the commercial mixture of extracts of Origanum vulgare, Rosmarinus officinalis, Lavandula officinalis, Cinnamomum zeylanicum, and Hidrastis canadensis [67]. In addition, the use of essential oils as cosmetic ingredients has several advantages, such as the improvement of the properties and the dermato-cosmetic presentation of a final product, with a better commercial image. Pharmaceutical technology is working in this line; for example, the studies of Khan et al. [68,69] and Sharif et al. [70] on human volunteers, in which skin aging was treated with plant-based emulsions, microemulsions, and nanoformulations. In the case of rosemary, its extracts act as potential stabilizers of a multiple emulsion (i.e., $\mathrm{W} / \mathrm{O} / \mathrm{W}$ ) [71]. In addition, 
the microencapsulation of its essential oils protect said oils from degradation and evaporation and, at the same time, subjects them to a controlled release [72]. The synthesis of terpolymeric capsules containing the essential oil of Rosmarinus officinalis is also being worked on, with the aim of using it as an antifungal component in cosmetics [73].

The European Commission defines a cosmetic as any substance or mixture intended to be put in contact with the superficial parts of the human body (e.g., the epidermis, hair and capillary system, nails, lips, and external genital organs) or with the teeth and oral mucous membranes, with the exclusive or main purpose of cleaning them, perfuming them, modifying their appearance, protecting them, keeping them in good condition, or correcting bodily odors. The difference between drugs and cosmetics is that cosmetics are not intended to cure or diagnose a disease. Therefore, we must consider rosemary as a cosmeceutical product [74]. Ávila-Sosa et al. [75] recommended its cutaneous use as an adjunct in the relief of minor muscle and joint pain. Its dosage is based on tradition, using it for a period of two weeks. They emphasized that the use of rosemary extract is not recommended for acute skin diseases, high fever, serious infections, circulatory disorders, or heart failure.

Fiume et al. [49] found, in a study conducted in the United States, that rosemary can be observed in 729 formulations. Its essential oil (usually used in fragrances) and leaf extract (as a skin conditioner) were found to have 474 and 404 uses, respectively. These authors found that most cosmetic formulations contain very low concentrations of ingredients derived from $R$. officinalis, often less than $0.1 \%$. However, they reported that $R$. officinalis leaf extract is used up to $10 \%$ in hand and body products and $3 \%$ in formulations for eyeshadows, soaps, and detergents. Based on these results, the use of rosemary in cosmetics is considered safe, although a case was reported of keratitis in a person who regularly ate foods flavored with rosemary [76], and isolated cases of professional dermatitis in people who grew rosemary have been reported $[77,78]$.

Androgenic alopecia (AGA) is the most common type of baldness among the male population (it also affects women to a lesser extent) and is due to the increased action of androgens on the scalp, producing a decrease and atrophy of the hair follicle and resulting in hair loss. Much of this is due to the action of dihydrotestosterone (DHT), which comes from the reduction of testosterone catalyzed by $5 \alpha$-reductase (Figure 8) [79].

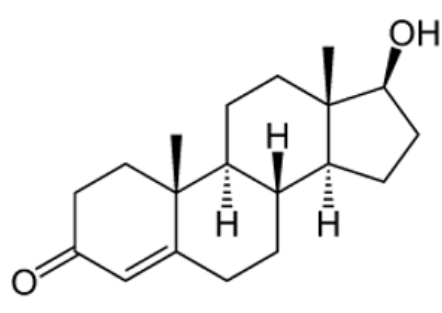

Testosterone

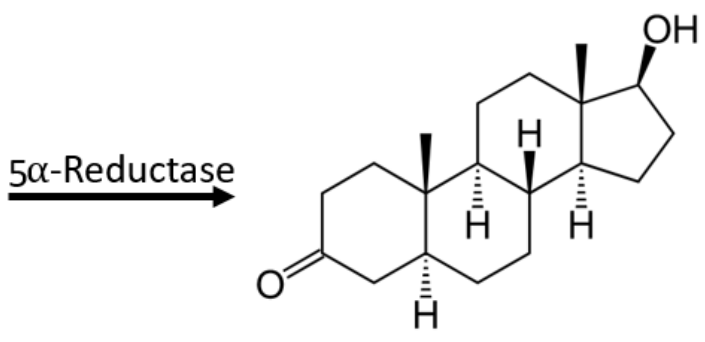

Dihydrotestosterone

Figure 8. Reduction of testosterone to dihydrotestosterone.

Based on our experience of Spanish pharmacies, rosemary alcohol is sold and people demand it to treat friction irritation and frictional alopecia; that is, there is a belief that rosemary prevents hair loss. As a curious case, we include an interesting formula that appeared in a theoretical-practical guide for pharmacists, doctors, and veterinarians in the year 1917 [80]:

For friction in alopecia:

Acetic acid $2-5 \mathrm{~g}$

Rosemary tincture $25 \mathrm{~g}$

Jarobardi tincture $25 \mathrm{~g}$

Quinine tincture $25 \mathrm{~g}$

Water 50-60 g 
These and more antecedents are the basis of the investigations addressing the anti-alopecia properties of rosemary. Panahi et al. [81] treated two groups of volunteers suffering from AGA $(n=50)$ for six months, one with rosemary oil and the other with minoxidil at $2 \%$. The final result was an improvement in the capillary count in the two cases without significant differences, but the rosemary group reported less itchy scalps.

In a study by Murata et al. [79], hair growth in mice was enhanced with rosemary leaf extracts (RO-ext) at topical doses of $2 \mathrm{mg} /$ day/mouse. The mice were pre-treated with testosterone. The same authors demonstrated that the hair regrowth was due to the inhibition of $5 \alpha$-reductase induced by the action of 12-methoxyrososic acid. In turn, they indicated that 12-methoxycarnosic acid plus rosemary extract can inhibit the binding of DHT to the androgen receptors in the hair follicle.

According to a review by Dhariwala et al. [82], rosemary works by improving blood circulation and vascularization, helping the regeneration of follicles with an effect similar to minoxidil, but with the use of rosemary extract, better results were not obtained than with minoxidil in the treatment of androgenic alopecia. Those authors also conducted a review of other plants that can be used in AGA: saw palmetto (Serenoa repens), green tea (Camellia sinensis), pumpkin seed (Curcurbita pepo), grape seed (Vitis vinifera), and licorice (Glycyrrhiza glabra).

To conclude, we will briefly comment on other studies that have been carried out with rosemary derivatives in order to incorporate it into topical preparations, to achieve a good skin condition and prevent diseases, specifically for melanoma [83], solar photoprotection [84,85], viruses [86], dermatomycosis [87,88], cellulitis [89], and pain [90].

Nolkemper et al. [86] examined the antiviral activity of aqueous extracts of Labiatae species against herpes simplex. Extracts of lemon balm (Melissa officinalis), peppermint (Mentha $\times$ piperita), prunella (Prunella vulgaris), rosemary (Rosmarinus officinalis), sage (Salvia officinalis), and thyme (Thymus vulgaris) were examined. Rosemary's inhibitory activity against herpes simplex virus type 1 (HSV-1), type 2 (HSV-2), and an acyclovir resistant strain of HSV-1 (ACV (res)) was tested in vitro in RC-37 cells. All test compounds showed high antiviral activity against HSV-1, HSV-2, and ACV (res). To identify the antiviral mode of action, the extracts were added to the virus cells at different stages of infection. Both types of herpes virus, as well as ACV (res), were considerably neutralized after treatment with the extracts before infection. These results indicate that the extracts affect HSV prior to adsorption but have no effect on intracellular virus replication. Therefore, the extracts exert their antiviral effect on free HSV and offer the opportunity to use them for topical therapeutic applications against recurrent herpes infections.

Mikaeili et al. [87] prepared a culture medium with agar to examine the fungicidal activity of the hydroalcoholic extract of rosemary in relation to Terbinafine. Microsporum canis and Trichophyton tonsurans were grown. The rosemary extract showed an inhibitory capacity on the growth of these dermatophytes, but this capacity was lower than the action of Terbinafine. Therefore, Sepahvand et al. [88] considered the extracts of rosemary and other Labiatae as a method to combat tinea, especially in countries with fewer resources to access conventional medicine.

Yimam et al. [89] conducted a double-blind trial with two groups of women with cellulite. One group was given a botanical topical cream with extracts of three correctly standardized plants (Rosmarinus officinalis, Annona squamosa, and Zanthoxylum clava-herculis) (cream UP1307). The other group was given an active comparator. After eight weeks in the first group, there were significant improvements in skin hydration, firmness, and elasticity.

To complete this list of the potential topical actions of rosemary, we point to the study of Akbari et al. [90], in which a group of rats responded to pain earlier with diclofenac sodium when formulated as a $1 \%$ rosemary scent gel, compared to diclofenac alone. The authors attributed the skin absorption promoting effect to 1,8-cineole. The study also demonstrated the potentiating effect of $0.5 \%$ and $1 \%$ rosemary essential oil on the percutaneous absorption of diclofenac. 


\section{Conclusions}

Rosmarinus officinalis (Labiatae) is an ancient plant considered to be medicinal in the European Pharmacopoeia. Through the centuries, it has been used empirically for multiple diseases. In the last few decades, in vitro, in vivo, and human trials have been carried out to establish scientific evidence for the medicinal properties attributed to this plant. Many of its molecules have also been identified thanks to new chemical tools. At least 150 molecules are known to be present in the volatile essential oil and fewer in the non-volatile fraction, such as carnosic acid, ursolic acid, oleanolic acid, flavonoids, and phenolic acids (rosmarinic acid). These molecules are precursors of plant derivatives with a high antioxidant capacity. Rosemary is widely used in cosmetic preparations as a fragrance and as a skin conditioner in safe concentrations. Rosemary preserves cosmetics from degradation and has great potential to be used topically. It absorbs UV light well and is a bactericidal and antifungal agent. Its anti-alopecia properties are also being studied. Thus far, it is only known that the benefits of this plant are associated with the synergistic action of its molecules or through synergistic action with other plant extracts. Further research may clarify its main bioactive molecules and their mechanism of action. At this time, we consider this plant as a cosmeceutical product, which helps maintain skin homeostasis and prevents the appearance of some skin diseases.

Funding: This research received no external funding.

Conflicts of Interest: The authors declare no conflict of interest.

\section{References}

1. Definición de Salud. Available online: https://www.who.int/es/about/who-we-are/frequently-asked-questions\#: ＼{\}:text=\%C2\%BFC\%C3\%B3mo\%20define \%20la\%20OMS\%20la, ausencia\%20de } \% 2 0 \text { afecciones\%20o\%20enfe } (accessed on 23 August 2020).

2. González-Minero, F.J.; Bravo-Díaz, L. Historia y actualidad de los productos para la piel, cosméticos y fragancias. Ars Pharm. 2017, 58, 5-12.

3. Zhang, 1.; Adique, A.; Sarkar, P.; Shenai, V.; Sampath, M.; Lai, R.; Qi, J.; Wang, M.; Miranda, A.; Farage, M.A. The Impact of Routine Skin Care on the Qualityof Life. Cosmetics 2020, 7, 59. [CrossRef]

4. Oumeish, Y. The Cultural and Philosophical Concepts of Cosmetics in Beauty and Art through the Medical History and Mankind. Clin. Derm. 2001, 19, 375-386. [CrossRef]

5. Aburjai, T.; Natsheh, F.M. Plants used in cosmetics. Phytother. Res. 2003, 17, 987-1000. [CrossRef] [PubMed]

6. Cronin, H.; Draelos, Z.D. Top 10 botanical ingredients in 2010 anti-aging creams. Cosmet. Derm. 2010, 9 , 218-225. [CrossRef]

7. Kumar, S. Exploratory analysis of global cosmetic industry: Major players, technology and market trends. Technovation 2005, 25, 1263-1272. [CrossRef]

8. Real Farmacopea Española. Available online: https://extranet.boe.es/farmacopea/doc.php?id=1560 (accessed on 23 August 2020).

9. Andrade, J.M.; Faustino, C.; García, C.; Ladeiras, D.; Reis, C.P.; Rijo, P. Rosmarinus officinalis L.: An update review of its phytochemistry and biological activity. Future Sci. OA 2018, 4, 283. [CrossRef]

10. Ribeiro-Santos, R.; Carvalho-Costa, D.; Cavaleiro, C.; Costa, H.S.; Gonçalves-Albuquerque, T.; Castilho, M.C.; Ramos, F.; Melo, N.R.; Sanches-Silva, A. A novel insight on an ancient aromatic plant: The rosemary (Rosmarinus officinalis L). Trends Food Sci. Technol. 2015, 45, 355-368. [CrossRef]

11. Sousa-Borges, R.; Sánchez-Ortiz, B.L.; Matías-Pereira, A.C.; Keita, H.; Tavares-Carvalho, J.C. Rosmarinus officinalis essential oil: A rewiew of the phytochemistry, anti-inflammatory activty, and mechanims of action involves. J. Etnopharmacol. 2019, 229, 29-45. [CrossRef]

12. De Oliveira, J.R.; Alfonso-Camargo, A.E.; Dias de Oliveira, L. Rosmarinus officinalis L. (rosemary) as therapeutic and prophylactic agent. Biomed. Sci. 2019, 26, 5. [CrossRef]

13. Malvezzi de Macedo, L.; Mendes dos Santos, E.; Militão, L.; Tundisi, L.; Ataide, J.A.; Barbosa-Souto, E.; Gava Mazzola, P. Rosemary (Rosmarinus officinalis L., syn Salvia rosmarinus Spenn.) and Its Topical Applications: A Review. Plants 2020, 9, 651. [CrossRef] [PubMed] 
14. Nicholson, P.T. Ancient Egyptian Materials and Technology; Cambridge University Press: Cambridge, UK, 2000; p. 175.

15. Muñoz-Centeno, L.M. Spanish Medicinal Plants. Rosmarinus officinalis L. (Lamiaceae) (Rosemary). Available online: http://revistas.usal.es/index.php/0211-9714/article/view/6111/6131 (accessed on 9 March 2020).

16. Flora of China. Available online: http://www.efloras.org/flora_page.aspx?flora_id=2 (accessed on 7 March 2020).

17. González-Bueno, A. Un Dioscórides para el Profano, Atribución, Significado y Utilidad de un Herbario Renacentista Castellano: El "Libro de las Yerbas" de Juan de Jarava; Colegio Oficial de Farmacéuticos: Burgos, Spain, 2006; p. 272.

18. Font-Quer, P. Plantas Medicinales. El Dioscórides Renovado; Península: Barcelona, Spain, 2007; p. 562.

19. Al-Sereitia, M.; Abu-Amerb, K.; Sena, P. Pharmacology of Rosemary (Rosmarinus officinialis Linn.) and Its Therapeutic Potentials. Ind. J. Exp. Biol. 1999, 37, 124-131.

20. Heinrich, M.; Kufer, J.; Leonti, M.; Pardo-de-Santayana, M. Ethnobotany and ethnopharmacologyInterdisciplinary links with the historical sciences. J. Ethnopharmcol. 2006, 107, 157-160. [CrossRef] [PubMed]

21. Elansary, H.O.; Mahmoud, N.A.; Shokralla, N.; Yessoufou, K. Diversity of Plants, Traditional Knowledge, and Practices in Local Cosmetics: A Case Study from Alexandria, Egypt. Econ. Bot. 2015, 30, 1-13. [CrossRef]

22. Theplanlist, Royal Botánical Gardens, Kew. Available online: http://www.theplantlist.org/ (accessed on 7 March 2020).

23. Begum, A.; Sandhya, S.; Shaff ath Ali, S.; Vinod, K.R.; Reddy, S.; Banji, D. An in-depth review on the medicinal flora Rosmarinus officinalis (Lamiaceae). Acta Sci. Pol. Technol. Aliment. 2013, 12, 61-73.

24. Morales, R. Flora Ibérica; CSIC: Madrid, Spain, 2010; Volume 12, pp. 321-327.

25. González-Minero, F.J.; González-García, A.; Venegas-Fito, C. Miscelánea Botánica. Apuntes Sobre los Herbarios y su Relación con la Farmacia; Ende: Sevilla, Spain, 2020; p. 43.

26. Drew, B.T.; González-Gallegos, J.G.; Xiang, C.L.; Kriebel, R.; Drummond, C.P.; Walker, J.V.; Kenneth, J. Salvia united: The greatest good for the greatest number. Taxon 2017, 66, 133-145. [CrossRef]

27. Global Biodiversity Information Facility-GBIF. Available online: https://www.gbif.org/ (accessed on 23 August 2020).

28. Tawfik, A.A.; Read, P.E.; Cuppett, S.L. Rosmarinus officinalis L. (Rosemary): In Vitro Culture, Regeneration of Plants, and the Level of Essential Oil and Monoterpenoid Constituents. Medicinal and Aromatic Plants; Springer-Verlag: Berlin/Heidelberg, Germany, 1998; pp. 349-365.

29. FAO/WHO. Comisión del Codex Alimentarius. Roma. 2013. Available online: http://www.fao.org/tempref/ codex/Meetings/CAC/cac36/cac36_10_add2s.pdf (accessed on 23 August 2020).

30. Christenhusz, M.J.M.; Fay, M.F.; Chase, M.W. Plants of the World. An Illustrated Encyclopedia of-Vascular Plants; Kew Publishing Royal Botanic Gardens: Kew, UK, 2017.

31. Castro de, M.; Martín-Vide, J.; Alonso, S. El Clima en España: Pasado, Presente y Escenario del Clima Para el Siglo XXI; Ministerio de Medio Ambiente: Madrid, Spain, 2005; p. 8.

32. Di Ferdinando, M.; Brunetti, C.; Agati, G.; Tattini, M. Multiple functions of polyphenols in plants inhabiting unfavorable Mediterranean areas. Environ. Exp. Bot. 2014, 103, 107-116. [CrossRef]

33. Thomson, J.D. Plant Evolution in the Mediterranean; Oxford University Press: New York, NY, USA, 2005; pp. 114, 144, 147.

34. Olmos, E.; Sánchez-Blanco, M.J.; Ferrández, T.; Alarcón, J.J. Subcellular Effects of Drought Stress in Rosmarinus officinalis. Plant Biol. 2007, 9, 77-84. [CrossRef]

35. Boix, Y.F.; Pimentel-Victório, C.; Antunes-Defaveri, A.C.; Arruda, R.D.; Sato, A.; Salgueiro Lage, C.L. Glandular trichomes of Rosmarinus officinalis L.: Anatomical and phytochemical analyses of leaf volátiles. Plant Biosyst. 2011, 145, 848-856. [CrossRef]

36. Staudta, M.; Bourgeoisa, I.; Al Halabia, R.; Song, W.; Williams, J. New insights into the parametrization of temperature and lightresponses of mono-and sesquiterpene emissions from Aleppo pineand Rosemary. Atmos. Environ. 2017, 152, 212-221. [CrossRef]

37. Diniz do Nascimento, L.; Moraes, A.; Barbosa de Costa, A.; Santana da, K.; Pereira Galucio, J.M.; Taube, P.S.; Costa, C.M.; Neves, C.; Jorddy de Aguiar, A.; Eloisa, H.; et al. Bioactive Natural Compounds and Antioxidant Activity of Essential Oils from Spice Plants: New Findings and Potential Applications. Biomolecules 2020, 7, 988. [CrossRef] [PubMed] 
38. Lee, C.J.; Chen, L.; Chang, T.; Ke, W.M.; Lo, Y.F.; Wang, C.C. The Correlation between Skin-Care Effects and Phytochemical Contents in Lamiaceae Plants. Food Chem. 2011, 124, 833-841. [CrossRef]

39. Base de Datos de Biodiversidad en España; CSIC: Madrid, Spain; Available online: http://www.anthos.es/ (accessed on 23 August 2020).

40. Gawel-Beben, K.; Kukula-Koch, W.; Hoian, U.; Czop, M.; Strzepek-Gomolka, M.; Antosiewicz, B. Characterization of Cistus x incanus L. and Cistus ladanifer L. Extracts as Potential Multifunctional Antioxidant Ingredients for Skin Protecting Cometics. Antioxidants 2020, 9, 202. [CrossRef] [PubMed]

41. Sharma, Y.; Velamuri, R.; Fagan, J.; Schaefer, J.; Streicher, C.; Stimson, J. Identification and characterization of polyphenols and volatile terpenoid compounds in different extracts of garden sage (Salvia officinalis L.). Pharmacog. Res. 2020, 12, 149-157. [CrossRef]

42. Shahbazian, D.; Karami, A.; Eshghi, S. Comparative Analysis of Essential Oils from Myrtus communis Berry Color Morphs from Southern Iran. Nat. Prod. J. 2018, 8, 317-322. [CrossRef]

43. El Hassouni, A.; El Bachiri, A.; Belbachir, C. Lavnadula dentata Solid Residue from Essential Oil Industry. J. Essent. Oil Bear Plants 2019, 22, 1601-1613. [CrossRef]

44. Pachi, V.; Mikropoulou, E.V.; Gkiouvetidis, P.; Siafakas, K.; Argyropoulou, A.; Angelis, A.; Mitakou, S.; Halabalaki, M. Traditional uses, phytochemistry and pharmacology of Chios mastic gum (Pistacia lentiscus var. Chia, Anacardiaceae): A review. J. Ethnophamacol. 2020, 254, 112485. [CrossRef]

45. Hernández, M.D.; Sotomayor, J.A.; Hernández, A.; Jordán, M.J. Rosemary (Rosmarinus officinalis L.) oils. In Esential Olis in Food Preservation, Flavor and Safety; Preedy, V., Ed.; Academic Press: London, UK, 2016; pp. 677-688.

46. Melito, S.; Petretto, G.L.; Chanhine, S.; Pintore, G.; Chessa, M. Seasonal variation of essential oil in Rosmarinus officinalis leaves in Sardinia. Nat. Prod. Comm. 2019, 14, 1-7. [CrossRef]

47. Hcini, K.; Sotomay, M.A.; Jordan, M.J.; Bouzid, S. Chemical composition of the essential oil of Rosemary (Rosmarinus officinalis L.) of Tunisian origin. As. J. Chem. 2013, 25, 2601-2603. [CrossRef]

48. Tahri, M.; Imelouane, B.; Aouinti, F.; Amhamdi, H.; Elbachiri, A. The organic and mineral compounds of the medicinal aromatics, Rosmarinus tournefortii and Rosmarinus officinalis, growing in eastern Morocco. Res. Chem. Int. 2013, 40, 2651-2658. [CrossRef]

49. Fiume, M.M.; Bergfeld, W.F.; Belsito, D.V.; Hill, R.A.; Klaassen, C.D.; Liebler, D.C.; Marks, J.G.; Shank, R.C.; Slaga, T.I.; Snyder, P.W.; et al. Safety Assessment of Rosmarinus officinalis (Rosemary)-Derived Ingredients as Used in Cosmetics. Int. J. Toxicol. 2018, 37, 125-150. [CrossRef]

50. Wang, B.; Ma, L.; Yin, L.; Chen, J.; Zhang, Y.; Dong, L.; Zhang, X.; Fu, X. Regional variation in the chemical composition and antioxidant activity of Rosmarinus officinalis L. from China and the Mediterranean region. Pak. J. Pharm. Sci. 2018, 31, 221-229. [PubMed]

51. Lakusic, D.; Ristic, M.; Slavkovska, V.; Lakusic, B. Seasonal variations in the composition of the essential oil of Rosemary (Rosmarinus officinalis, Lamiaceae). Nat. Prod. Comm. 2013, 8, 131-134.

52. González-Minero, F.J. Estudio transversal de Moringa oleifera Lam. (Moringaceae) Revisión. Dominguezia 2018, 34, 5-25.

53. Khan, B.A.; Akhtar, N.; Menaa, B.; Menaa, A.; Braga, V.A.; Menaa, F. Relative Free Radicals Scavenging and Enzymatic Activities of Hippophae rhamnoides and Cassia fistula Extracts: Importance for Cosmetic, Food and Medicinal Applications. Cosmetics 2017, 4, 3. [CrossRef]

54. Chávez-González, M.L.; Rodríguez-Herrera, R.; Aguilar, R. Essential oils: As natural alternative to combat antibiotics resistence. In Antibiotic Resistance Mechanisms and New Antimicrobial Approaches; Kon, K., Rai, M., Eds.; Elsevier: Amsterdam, The Netherlands, 2016; pp. 227-238.

55. Wang, W.; Li, N.; Luo, M.; Zu, Y.; Efferht, T. Anbibacterial activity abd anticancer activity of Rosmarinus officinalis L. essential oil compared to that of its main components. Molecules 2012, 17, 2704-2713. [CrossRef]

56. Genena, K.A.; Hense, J.A.; Smania, J.; Souza, M.A.S. Rosemary (Rosmarinus officinalis L.) a study of the composition, antioxidant and antimicrobial activities of extracts obtained with supercritical carbon dioxide. Cienc. Tecnol. Aliment. 2008, 28, 463-469. [CrossRef]

57. Hussain, A.I.; Anwar, F.; Chatha, S.A.S.; Jabbar, A.; Mahboob, M.; Nigam, P.S. Rosmarinus officinalis essential oil: Antiproliferative, antioxidant and antibacterial activities. Braz. J. Microbiol. 2010, 41, 10170-11078. [CrossRef]

58. Birtic, S.; Dussort, P.; Pierre, F.X.; Bily, A.C.; Roller, M. Carnosic acid. Phytochemistry 2015, 115, 9-19. [CrossRef] 
59. Menaa, F.; Menaa, A.; Tréton, J. Polyphenols against Skin Aging. In Polyphenols in Human Health and Disease; Watson, R.R., Preedy, V.R., Zibadi, S., Eds.; Academic Press: London, UK, 2014; pp. 819-830.

60. Calabrese, V.; Scapagnini, G.; Catalano, C.; Dinotta, F.; Geraci, D.; Morganti, P. Biochemical studies of a natural antioxidant isolated from rosemary and its application in cosmetic dermatology. Int. J. Tissue React. 2000, 22, 5-13.

61. EFSA. Use of rosemary extracts as a food additive. Scientific Opinion of the Panel on Food Additives, Flavourings, Processing Aids and Materials in Contact with Food. EFSA J. 2008, 721, 1-29.

62. EFSA Panel on Food Additives; Nutrient Sources added to Food (EFSA ANS Panel); Younes, M.; Aggett, P.; Aguilar, F.; Crebelli, R.; Dusemund, B.; Filipič, M.; Frutos, M.J.; Galtier, P.; et al. Refined exposure assessment of extracts of rosemary (E 392) from its use as food additive Panel on Food Additives and Nutrient Sources added to Food. EFSA J. 2018, 5373. [CrossRef]

63. Damianova, S.; Tasheva, S.; Stoyanova, A.; Damianov, D. Investigation of Extracts from Rosemary (Rosmarinus officinalis L.) for Application in Cosmetics. J. Essent. Oil Bear. Plants 2010, 13, 1-11. [CrossRef]

64. Muyima, N.Y.O.; Zulu, G.; Bhengu, T.; Popplewell, D. The potential application of some novel essential oils as natural cosmetic preservatives in an aqueous cream formulation. Flavour Fragr. J. 2002, 174, 258-266. [CrossRef]

65. Satyal, P.; Jones, T.H.; Lopez, E.M.; McFeeters, R.L.; Awadh Ali, N.A.; Mansi, I.; Al-kaf, A.G.; Setzer, W.N. Chemotypic Characterization and Biological Activity of Rosmarinus officinalis. Foods 2017, 6, 20. [CrossRef]

66. Gauch, L.D.R.; Soares-Pedrosa, S.; Antunes-Esteves, R.; Silveira-Gomes, F.; Cajueiro-Gurgel, E.S.; Marques-da-Silva, S.H. Antifungal activity of Rosmarinus officinalis Linn. essential oil against Candida albicans, Candida dubliniensis, Candida parapsilosis and Candida krusei. Rev. Pan-Amaz. Saude 2014, 5, 61-66. [CrossRef]

67. Varvaresou, A.; Papageorgiou, S.; Tsirivas, E.; Protopapa, E.; Kintziou, H.; Kefala, V.; Demetzos, C. Self-preserving cosmetics. Int. J. Cosmet. Sci. 2009, 31, 163-175. [CrossRef]

68. Khan, B.A.; Mahmood, T.; Menaa, F.; Shahzad, Y.; Yousaf, A.M.; Hussain, T.; Ray, S.D. New Perspectives on the Efficacy of Gallic Acid in Cosmetics \& Nanocosmeceuticals. Curr. Pharm. Des. 2018, 24, 5181-5187.

69. Khan, B.A.; Akhtar, N.; Menaa, A.; Menaa, F. A Novel Cassia fistula (L.)-Based Emulsion Elicits Skin Anti-Aging Benefits in Humans. Cosmetics 2015, 2, 368-383. [CrossRef]

70. Sharif, A.; Akhtar, N.; Khan, M.S.; Menaa, A.; Menaa, B.; Khan, B.A.; Menaa, F. Formulation and evaluation on human skin of a water-in-oil emulsion containing Muscat hamburg black grape seed extract. Int. J. Cosmet. Sci. 2015, 7, 253-258. [CrossRef]

71. Cizauskaite, U.; Ivanauskas, L.; Jakštas, V.; Marksiene, R.; Jonaitiene, L.; Bernatoniene, J. Rosmarinus officinalis L. extract and some of its active ingredients as potential emulsion stabilizers: A new approach to the formation of multiple (W/O/W) emulsion. Pharm. Dev. Technol. 2016, 21, 716-724. [PubMed]

72. Carvalho, I.T.; Estevinho, B.N.; Santos, L. Application of microencapulated essential oils in cosmetic and personal healthcare products-A review. Int. J. Cosm. Sci. 2016, 3, 109-119. [CrossRef] [PubMed]

73. Silva-Neves, J.; Lopes-da-Silva, Z.; de Sousa Brito Neta, M.; Braun-Chaves, S.; de Medeiros- Nobrega, I.K.; de Lira-Machado, A.H.; Machado, F. Preparation of terpolymer capsules containing Rosmarinus officinalis essential oil and evaluation of its antifungal activity. RSC Adv. 2019, 9, 22586. [CrossRef]

74. Reglamento Europeo. Available online: https://eur-lex.europa.eu/LexUriServ/LexUriServ.do?uri=OJ:L:2009: 342:0059:0209:es:PDF (accessed on 23 August 2020).

75. Avila-Sosa, R.; Navarro-Cruz, A.R.; Vera-López, O.; Dávila-Márquez, R.M.; Melgoza-Palma, N.; Meza-Pluma, R. Romero (Rosmarinus officinalis L.): Una revisión de sus usos no culinarios. Cienc. Mar. 2011, 16, 923-936.

76. Guin, J.D. Rosemary cheilitis: One to remember. Contact Dermat. 2001, 45, 63. [CrossRef]

77. Inui, S.; Katayama, S. Allergic Contact Dermatitis Induced by Rosemary Leaf Extract in a Cleansing Gel. J. Dermatol. 2005, 32, 667-669. [CrossRef]

78. Miroddi, M.; Calapai, G.; Isola, S.; Minciullo, P.L.; Gangemi, S. Rosmarinus officinalis L. as cause of contact dermatitis. Allergol. Inmonpathol. 2014, 42, 616-619. [CrossRef]

79. Murata, K.; Noguch, K.; Kondo, M.; Onishi, M.; Watanabe, N. Promotion of Hair Growth by Rosmarinus officinalis Leaf Extract. Phytother. Res. 2013, 27, 212-217. [CrossRef]

80. Medicamenta. Guía Teórico-Práctica Para Farmacéuticos, Médicos y Veterinarios; Labor: Barcelona, Spain, 1917; p. 969. 
81. Panahi, Y.; Taghizadeh, M.; Tahmasbpour-Marzony, E.; Sahebkar, A. Rosemary oil vs minoxidil 2\% for the treatment of androgenetic alopecia: A randomized comparative trial. Skinmed 2015, 13, 15-21.

82. Dhariwala, M.J.; Ravikumar, P. An overview of herbal alternatives in androgenetic alopecia. J. Cosmet. Dermatol. 2019, 18, 966-975. [CrossRef]

83. Cattaneo, L.; Cicconi, R.; Mignogna, G.; Giorgi, A.; Mattei, M.; Graziani, G.; Ferracane, R.; Grosso, A.; Aducci, P.; Schininà, M.E.; et al. Anti-Proliferative Effect of Rosmarinus officinalis L. Extract on Human Melanoma A375 Cells. PLoS ONE 2015, 10, e0132439. [CrossRef] [PubMed]

84. Offord, E.A.; Gautier, J.C.; Avanti, O.; Scaletta, C.; Runge, F.; Krämer, K.; Applegate, L.A. Photoprotective potential of lycopene, beta-carotene, vitamin $\mathrm{E}$, vitamin $\mathrm{C}$ and carnosic acid in UVA-irradiated human skin fibroblasts. Free Radic. Biol. Med. 2002, 32, 1293-1303. [CrossRef]

85. Pérez-Sánchez, A.; Barrajón-Catalán, E.; Caturla, N.; Castillo, J.; Benavente-García, O.; Alcaraz, M.; Mico, V. Protective effects of citrus and rosemary extracts on UV-induced damage in skin cell model and human volunteers. J. Photochem. Photobiol. 2014, 136, 12-18. [CrossRef] [PubMed]

86. Nolkemper, S.; Reichling, J.; Stintzing, F.C.; Carle, R. Antiviral effect of aqueous extracts from species of the Lamiaceae family against Herpes simplex virus type 1 and type 2 in vitro. Plant Med. 2006, 72, 1378-1382. [CrossRef]

87. Mikaeili, A.; Modaresi, M.; Sozani, S.; Karimi, I. The Antifungal Activities of Rosemary against Trichophyton Tonsurans and Microsporum Canis. Int. J. Pharm. Res. Allied Sci. 2016, 5, 472-483.

88. Sepahvand, A.; Elliasy, H.; Mohammadi, M.; Safarzadeh, A.; Azarbaijani, K.; Shahsavari, S.; Alizabeh, M.; Beyranvaand, F. A review of the most effective medicinal plants for dermatophytosis in traditional medicine. Biomed. Res. Ther. 2018, 5, 2378-2388. [CrossRef]

89. Yimam, M.; Lee, Y.; Giao, P.; Hong, M.; Brownell, L.; Jia, Q. A Standardized Composition Comprised of Extracts from Rosmarinus officinalis, Annona squamosa and Zanthoxylum clava-herculis for Cellulite. Pharmacog. Res. 2017, 9, 319-324. [CrossRef]

90. Akbari1, J.; Saeedi1, M.; Farzin, D.; Morteza-Semnani, K.; Esmaili, Z. Transdermal absorption enhancing effect of the essential oil of Rosmarinus officinalison percutaneous absorption of Na diclofenac from topical gel. Pharm. Biol. 2015, 53, 1442-1447. [CrossRef]

(C) 2020 by the authors. Licensee MDPI, Basel, Switzerland. This article is an open access article distributed under the terms and conditions of the Creative Commons Attribution (CC BY) license (http://creativecommons.org/licenses/by/4.0/). 